\title{
血栓性微小血管症（TMA）と播種性血管内凝固（DIC）の 早期鑑別診断
}

矢田憲孝*，西尾健治

\section{Early differential diagnosis between thrombotic microangiopathy (TMA) and disseminated intravascular coagulation (DIC)}

Noritaka YADA, Kenji NISHIO

\begin{abstract}
要約：血栓性微小血管症（thrombotic microangiopathy: TMA）は血小板減少・臟器障害・溶血性貧血を呈する比 較的稀な病態であり, 血栓性血小板減少性紫斑病（thrombotic thrombocytopenic purpura: TTP）, 志賀毒素産生大 腸菌による溶血性尿毒症症候群（Shiga toxin-producing Escherichia coli-hemolytic uremic syndrome: STEC-HUS）, 非典型溶血性尿毒症症候群（atypical HUS: aHUS），二次性 TMA に分類される．類似の症状をきたす病態とし ては播種性血管内凝固（disseminated intravascular coagulation: DIC）の頻度が高く, TMAも DIC も早期治療が予 後を左右するため, これらの早期鑑別が問題になることがある. 血小板減少・臟器障害・溶血性貧血の診療に おいてはTMA を疑うことが大切であり，そのために最も重要な点は溶血性貧血に気付くことである. 溶血性 貧血に気付くことが出来れば, ADAMTS13 活性など確定診断に必要な検査を提出し, その結果を得るまでに TMA 抢よびDIC の早期鑑別診断を進める. PLASMIC score, 腸炎症状, 原因疾患, 家族歴・既往歴, 溶血所 見・凝固異常の程度などを指標に可能性の高い疾患を選び出して早期治療を開始しつつ, 確定診断が得られる までは常に他の TMA や DIC の可能性も念頭に置いて, 治療経過の中で繰り返し判断することが重要である.
\end{abstract}

Key words: TTP, STEC-HUS, aHUS, secondary TMA, ADAMTS13, PLASMIC score

\section{TMA と DIC の鑑別のポイント}

】血小板減少・臟器障害・溶血性貧血の診療におい て大切なのは TMA を疑うことであり, そのために 最も重要な点は溶血性貧血に気付くことである.

口TMA も DIC も早期治療が予後を左右するため, 早期鑑別して治療を開始しつつ, 確定診断までは常 に他の TMA や DIC の可能性も並列で考えながら, 治療経過の中で繰り返し判断する姿勢が重要である. ØTTPの早期鑑別診断：TTP 診断のゴールドスタン ダードはADAMTS13 活性だが，その結果を得るま でに, 特に後天性 TTP と敗血症性 DIC の早期鑑別が

*責任者連絡先：

奈良県立医科大学総合医療学講座

干 634-8522 奈良県橿原市四条町 840

Tel: 0744-29-8905, Fax: 0744-24-5739

E-mail: n-yada@naramed-u.ac.jp
問題となる場合があり, PLASMIC score, 溶血所見 の程度 ( $\mathrm{LDH}, \mathrm{Hb})$, 線溶抑制の程度 (FDP, Ddimer）が早期鑑別に有用である.

ØSTEC-HUS の早期鑑別診断：STEC-HUS 診断の ゴールドスタンダートはSTECの確認だが, その結 果を得るまでに, 腸炎症状を伴う DIC や他の TMA との早期鑑別が問題となる場合があり, 画像検査 (著 明な大腸壁肥厚）が早期鑑別に有用である.

口二次性 TMA の早期鑑別診断 : 二次性 TMA をきた す原因を特定して診断するが, 原因の種類や併存症 によっては DIC や AHUS との鑑別が問題となること があり, DIC との鑑別では溶血所見・凝固異常の程 度を, aHUS との鑑別では治療反応性を指標に早期 診断する.

ØaHUS の早期鑑別診断：aHUS の確定診断は遺伝子 検査だが, 結果を得るのに時間を要するため, 補体 関連異常の家族歴・既往歴および補体価（C3 低下） 
を確認し, 治療反応性も含めて他の TMA と DIC を 除外し, 臨床的 aHUS と早期診断する. DIC との鑑 別では, 溶血所見・凝固異常の程度を指標にする.

\section{はじめに}

血栓性微小血管症（thrombotic microangiopathy: TMA）は，全身の微小血管で血小板血栓が形成され た結果, 血小板減少, 血小板血栓性臓器障害, 微小 血管障害性溶血性貧血を呈する疾患群である ${ }^{1)}$ 。一 方, 播種性血管内凝固 (disseminated intravascular coagulation: DIC) は, 敗血症や悪性腫瘍などの原因 疾患に伴って凝固活性が充進し, 全身の細小血管内 でフィブリン血栓を生じ, その結果として消耗性血 小板減少, 血检性臓器障害, 消耗性凝固因子久乏 (出 血傾向）をきたす病態である ${ }^{2)}$. TMA は血小板血 栓, DIC はフィブリン血栓が本態であるがいずれも 血小板減少と臓器障害を呈し, また DICでも軽度の 溶血を伴うことがある.さらに, TMA でも病勢が強 ければフィブリン血栓も伴い凝固異常を呈し, DIC でも血小板血栓を伴うため, 検査值も類似すること がある。

以上のように, TMA と DIC の早期鑑別が臨床上 で重要となるため, まず TMA と DIC の病態・治療 について触れ，その次に両者の早期鑑別診断につい て述べる。

\section{TMA の病態と治療}

各 TMA については別稿に記載があるため, 本稿 では簡単に触れる. TMA は, 血栓性血小板減少性紫 斑病 (thrombotic thrombocytopenic purpura: TTP), 志 賀毒素産生大腸菌による溶血性尿毒症症候群 (Shiga toxin-producing Escherichia coli-hemolytic uremic syndrome: STEC-HUS), 非典型 HUS (atypical HUS: aHUS), 二次性 TMA に分類される ${ }^{3)}$.

TTP は von Willebrand factor (VWF) の切断酵素で あるADAMTS13 の活性が著減して血小板血栓を形 成する疾患であり, ADAMTS13 活性が $10 \%$ 未満の ものが TTP と定義される ${ }^{4)}$. TTP 患者の救命には早 期治療が重要であり, 特に後天性 TTP では早期の血
漿交換, さらに難治例でリツキシマブの投与が必要 となるが効果発現までに時間を要する5). そのため, ADAMTS13の結果を待つまでに治療開始が必要とな り, 早期診断および難治例の早期判別が重要となる。 HUS は血小板減少・急性腎障害・溶血性貧血の臨 床症状を呈する疾患であり ${ }^{6)}$, 多くは STEC の経口 摂取で発症するSTEC-HUS である7). STEC-HUS は 志賀毒素 (Shiga toxin: Stx) の蛋白合成阻害 ${ }^{8}$ によ り血管内皮障害を生じることで発症し ${ }^{9)}$, STEC の証 明により確定診断する. STEC-HUS 治療の基本は支 持療法（点滴などの全身管理）だが, 脳症合併時に は血漿交換を要する例もあり ${ }^{10,11)}$, 確定診断の検査 結果を得る前に早期治療を要することがある.

aHUS は, 補体関連因子の異常で自己の血管内皮 が障害されることで発症する ${ }^{12)}$.「aHUS 診療ガイド ライン 2015」13) では, TMAのうち TTP, STECHUS, 二次性 TMA を除外したものがaHUS と定義さ れた。 aHUSは末期腎不全に至る予後不良の疾患で あり早期治療が必要だが, 確定診断のための遺伝子 検査結果を待つことは難しく, 他の TMA および DIC を臨床的に除外し治療を開始する。 aHUSでは血漿 交換およびエクリズマブが有効だが ${ }^{14)}$, 二次性 TMA ではエクリズマブは適応とならず ${ }^{15)}$, DIC も治療法 が大きく異なるため, これらとの早期鑑別が特に重 要となる.

二次性 TMA は自己免疫疾患, 感染症, 悪性腫瘍 などの原因があって発症する TMA と定義される ${ }^{16)}$. 原因が確定しにくい場合, DIC や aHUS との鑑別が 問題になる。 二次性 TMA は原因に対する治療が基 本であり（膠原病による二次性 TMA に対するステ ロイド治療など), 重症例で血漿交換が必要となるこ とがある。

\section{DIC の病態と治療}

DIC 診断のゴールドスタンダードは定まっていな いが, 旧厚生省 DIC 診断基準 (旧基準), 国際血栓 止血学会 DIC 診断基準 (ISTH 基準), 日本救急医学 会急性期 DIC 診断基準 (急性期基準), 日本血栓止 血学会 DIC 診断基準 (JSTH 基準) などが用いられ

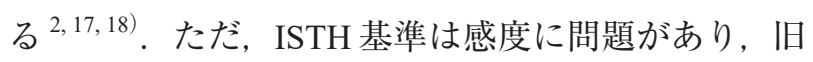


基準は敗血症において感度が悪いとされる．急性期 基準は敗血症において感度が良いが, 特異度が低い (当科で TTP と確定診断した症例において7割近く が初療時に急性期基準を満たしていた)。近年，これ らの問題点を踏まえ原因疾患別に診断基準を設定し た JSTH 基準が作成され，活用されるようになって きている。

DIC は線溶反応の程度により, 線溶抑制型・線溶 均衡型 (中間型) ・ 線溶克進型に分類される ${ }^{19)}$. 線 溶元進型 DICでは, 凝固活性元進により D-dimer や thrombin antithrombin complex（TAT）も高值となる が，それ以上に線溶立進による fibrin and fibrinogen degradation products (FDP) や plasmin- $\alpha 2$ PI complex （PIC）の増加が著しいため ${ }^{20)}$, FDP 上昇と D-dimer 上昇の程度などを参考に線溶抑制型 DIC と線溶克進 型 DIC を鑑別する. 線溶光進型 DIC を呈する疾患と しては, 前立腺癌・肺癌などの plasminogen activator （PA）産生腫瘍や, PA 以外の線溶物質を伴う急性前 骨髄球性白血病などがあり, 出血症状は高度である ものの臓器症状は少ない. 線溶抑制型 DIC を呈する 代表疾患は敗血症であり, 凝固活性が充進する一方 で plasminogen activator inhibitor-I（PAI-I）が著増し, 線溶が抑制されることで血栓性 (虚血性) 臓器症状 が出現しやすく, 重症例や治療開始が遅れた場合に は多臓器不全に至り予後不良となる。 そのため, 特 に感染 focus がはっきりしないものの敗血症性 DIC が疑われる状況で TMA との早期鑑別が問題となる.

敗血症性 DICでは早急な全身管理と感染巣コント ロールが必要となり, Surviving Sepsis Campaign Guideline で推奨される敗血症バンドルに沿った治療 が行われる ${ }^{21)}$. 敗血症バンドルのうち, 乳酸值測 定, 血液培養採取, 広域抗菌薬投与, 低血圧・高乳 酸血症への晶質液投与の項目については 3 時間以内 の達成が目標とされており, 達成までの時間と死亡 率が相関することが示されている ${ }^{22)}$. さらに, 敗血 症性 DICでは過剩な炎症・凝固などの生体防御反応 を適度に制御することも重要となる。例えば，アン チトロンビン（AT）活性が低下している敗血症性 DIC は予後不良であり ${ }^{23)}$ ，重症例において $\mathrm{AT}$ 製剤 による生存率の改善が報告されている ${ }^{24,25)}$. また, 抗凝固治療として用いられるリコンビナントトロン
ボモジュリン（rTM）は抗炎症作用や AT 温存効果も 期待され ${ }^{26)}$, 重症例で rTM 製剤が併用されることが ある 27).

実際には, 血小板減少と臓器障害をきたす疾患と しては敗血症性 DIC の頻度が高いため, 血小板減少 と臓器障害を認め敗血症性 DICが疑われた場合, ま ず先述の敗血症性 DIC に対する治療を行いながら, 一方で比較的稀な TMAについても並行して疑って おく必要がある。そして, 経過から TMAも疑われ る状態であれば, TMA と DICの早期鑑別診断（後 述）に沿って繰り返し判断することが重要となる。

\section{3. 血小板減少・臓器障害・溶血性貧血を呈する 病態（TMA と DIC）の早期鑑別診断（図 1）}

血小板減少と臓器障害を呈する病態の中で, TMA は比較的稀であり, DICの頻度が高い. また, TMA と DIC はいずれも救命のために早期治療介入が必要 だが両者の治療法は異なるため, TMA と DICをい かに早期に鑑別し適切な治療を開始できるかが予後 を左右する。つまり, 血小板減少・臓器障害・貧血 を呈する症例に遭遇した際に, 頻度の高い DIC のみ ならず比較的稀な TMA も疑えるかどうかが重要と なる，そして，TMAを疑うことが出来るか否かで重 要となるのが,「溶血性貧血」に気付くことである. 溶血性貧血に気付くためには，Hb，LDH，尿潜血， 破砕赤血球に普段から注意する必要がある。 日々の 診療において, $\mathrm{Hb}$ 低下があっても顕著でなければす ぐには貧血の原因が厳密に鑑別されないことがある. LDH は溶血以外の原因で上昇することも多く, LDH 上昇が著明でなければ溶血所見として意識されにく い. 尿潜血も他の病態でもよく認められるため, 溶 血所見として捉えられにくい. 破砕赤血球は少数で あれば検査室で目視されないことも多く，目視を依 頼することが必要である。また，ハプトグロビンが 溶血性貧血の診断に有用であるが，日常のルーチン 検査に含まれることは少なく, すぐに結果が得られ ないこともあり, むしろ溶血にある程度気付いた状 況で測定されることが多い，そのため，まず溶血性 貧血を疑えるかどうかが key pointであり, Hb 低下. LDH 上昇のバランスなどを日々の診療の中で意識し 


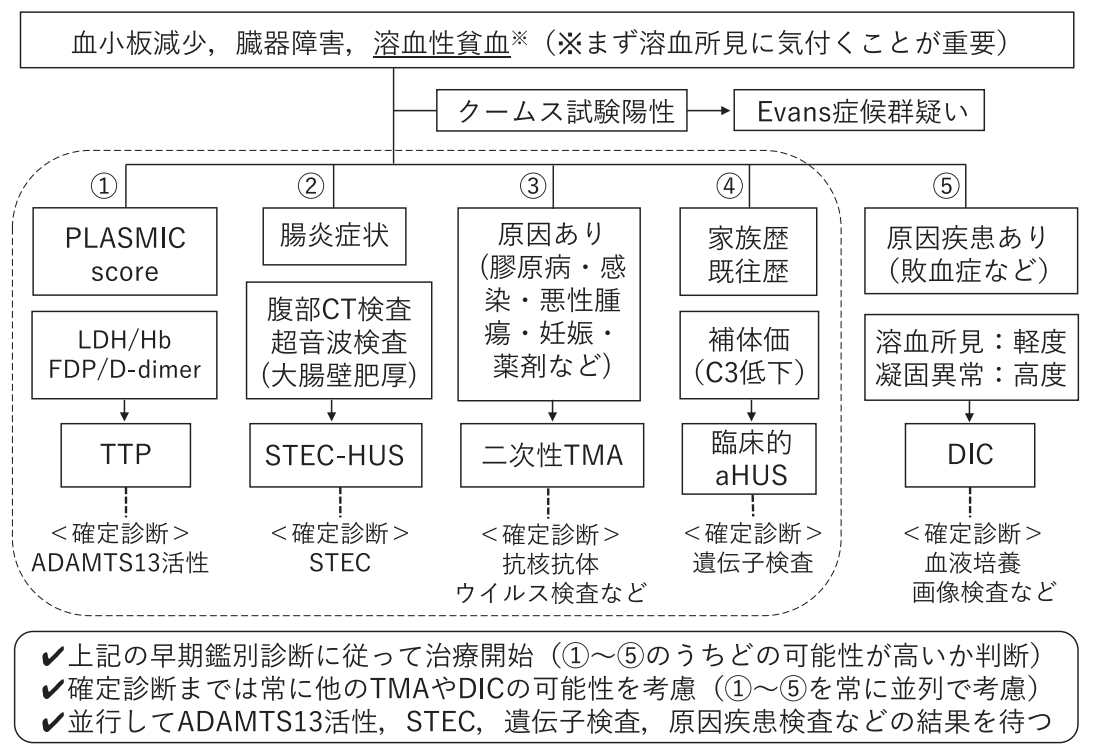

困 1 血小板減少・臓器障害・溶血性貧血（TMA と DIC）の早期鑑別診断

ておくことが重要である. 溶血所見に気付くことが 出来れば，TMAおよび DIC の鑑別に進むことが出 来る。

血小板減少・臟器障害・溶血性貧血を呈する病態 （TMA と DIC）の早期鑑別診断フローチャートを示 す（図 1)。まずクームス試験が陰性であればTMA および DICの鑑別に進み, 各 TMA およびDICの早 期鑑別点に沿って早期診断し治療を開始する（図 1 の(1)〜(5), 詳細後述)。ただし，これらの鑑別点のみ で他の TMA および DIC を完全に除外するのは難し い. そのため, 早期鑑別診断で可能性の高い疾患を 選び出して治療を開始し, 確定診断までは常に他の TMA および DIC の可能性も並列で考慮し, 治療反 応性も含めて判断しながら, ADAMTS13 活性や確定 診断に必要な検査の結果を待つ.

(1)TTPの PLASMIC score 用いた早期鑑別診断 〜特に後天性 TTP と敗血症性 DIC の早期鑑別〜

TTPの早期診断に，最近は PLASMIC scoreが用い られる. TTPの早期診断で問題となりやすいのが後 天性 TTP と敗血症性 DIC（特に感染 focus がはっき りしない case）の鑑別であり, TTPで溶血所見が強く 敗血症性 DIC で凝固異常が強い傾向はあるものの, 両者の特徵は類似しており鑑別が難しい（表 1 ${ }^{28)}$.
そこで, 血小板減少をきたす疾患の早期鑑別の必要 性を背景に, TTP (ADAMTS13 活性 10\%未満) を予 測するPLASMIC scoreが提唱され ${ }^{29)}$, その有用性が 示された ${ }^{30)}$ 。なお, PLASMIC scoreの詳細について は別稿に記載があるため本稿では割愛する.

TTP の PLASMIC score 用いた早期鑑別診断フ ローチャートを示す（図 2).PLASMIC score の全 7 項目のうち 6 点以上であればTTPの可能性が高いと 判断し, 血漿交換を開始しつつ ADAMTS13 活性の 結果を待つ. PLASMIC score が 5 点以下の場合でも TTP の否定はできず ${ }^{31)}$, 自験例でも PLASMIC score が 5 点以下で最終診断が TTP の症例があった。一方 で, PLASMIC score が 5 点で最終診断が DIC の症例 もあった。 そのため, 当科では PLASMIC score と併 せて, 溶血性貧血の程度 ( $\mathrm{Hb}$ 低下と $\mathrm{LDH}$ 上昇のバ ランス）および凝固線溶異常のパターン（FDP 上昇 と D-dimer 上昇のバランス）も指標としている. DIC はTTP（おょび他の TMA）よりも溶血性貧血が顕著 ではないため, Hb 低下の程度に比して LDH 上昇が 軽度であり，TTP と比べて $\mathrm{LDH} / \mathrm{Hb}$ 比が低い傾向を 示す。また, 敗血症性 DIC は線溶抑制が強いため FDP が著増せず ${ }^{19,32)}$, TTP と比べて FDP/D-dimer 比 が低い傾向がみられる。 さらに, 敗血症性 DICでは $\mathrm{AT}$ 活性が TTP より低值になることが多い. 以上か 
表 1 後天性 TTP と敗血症性 DIC の特徴

\begin{tabular}{|l|l|l|}
\hline & \multicolumn{1}{|c|}{ 後天性 TTP } & \multicolumn{1}{c|}{ 敗血症性 DIC（線溶抑制型 DIC） } \\
\hline 臨床症状 & 臟器症状（精神神経症状, 腎障害) & 臟器症状（特に腎障害） \\
\hline 血小板数 & 著減 & 著減（急激な低下） \\
\hline FDP & 正常〜軽度上昇 & 軽度上昇 \\
\hline PT & 正常〜軽度延長 & 延長 \\
\hline APTT & 正常 & 正常〜軽度延長 \\
\hline アンチトロンビン & 正常（肝不全があれば低下） & 低下 \\
\hline LDH & 増加（特徵的） \\
\hline 破砕赤血球 & あり（特徵的） & 原因疾患や併存症（横紋筋融解など）により上昇することあり \\
\hline ハプトグロビン & 感度以下 (特徵的) & 通常正常（肝不全があれば低下） \\
\hline
\end{tabular}

TTP: thrombotic thrombocytopenic purpura, DIC: disseminated intravascular coagulation, FDP: fibrin and fibrinogen degradation products, PT: prothrombin time, APTT: activated partial thromboplastin time, LDH: lactate dehydrogenase.

(文献 28 より引用; 一部改変)

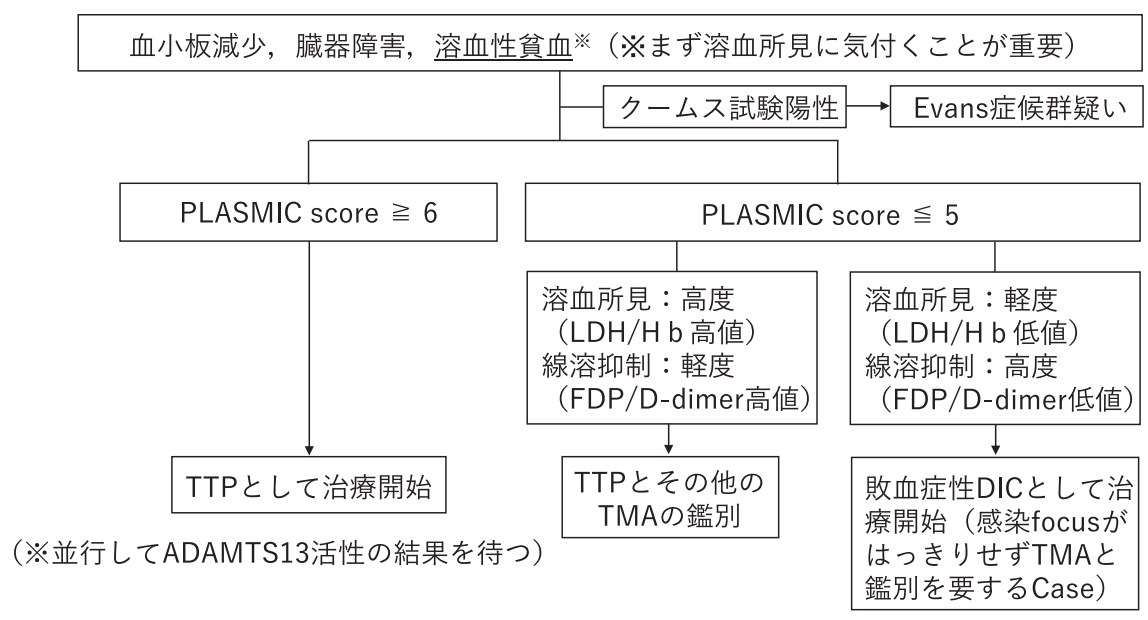

上記の早期鑑別診断に従って治療開始（TTP：血漿交換，DIC：抗菌薬など）

確定診断までは常に他のTMAやDICの可能性を考慮（図1の(1)〜5)を参照）

並行してADAMTS13活性, STEC, 遺伝子検査, 原因疾患検査などの結果を待つ

図 2 TTP の PLASMIC score を用いた早期鑑別診断（図 1 の1)詳細）

ら, PLASMIC score が 5 点以下の症例では, これら の指標も用いて後天性 TTP と敗血症性 DIC を鑑別 し，早期治療を開始する。

(2)STEC-HUS の腹部画像検査を用いた早期鑑別診断 〜腸炎症状を伴う DIC ・ TMA の早期鑑別〜

血小板減少・臓器障害・溶血性貧血に加え, 典型 的な臨床症状（腹痛, 下痢, 血便など）があれば
STEC-HUS を疑うことは比較的容易である．STEC 感染症では著明な大腸壁肥厚が特徵的であり（図 $3)^{10)}$, STEC-HUS の早期診断に画像評価（腹部 CT, 超音波検査）が有用である ${ }^{33)}$ 。また, STEC-HUS で は LDH 上昇が早期からみられることも特徵であ る $^{34)}$.

STEC-HUS と腸炎症状を伴う DIC や他の TMA と の鑑別を要する場合があり, 早期鑑別診断の手順を 


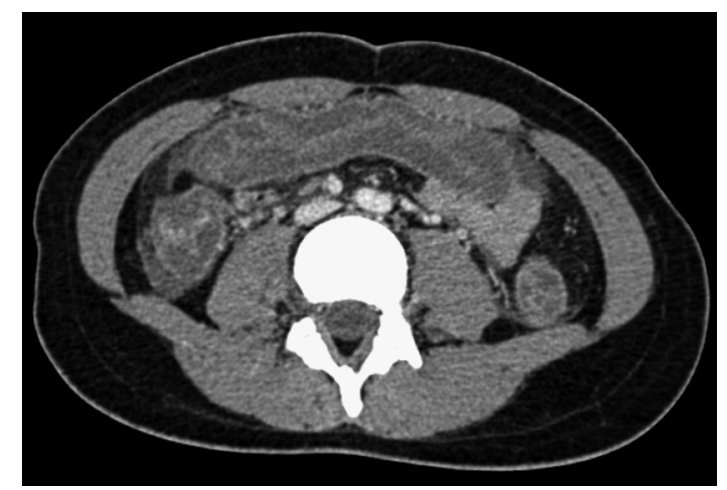

図 3 STEC-HUS における大腸壁肥厚（腹部 CT 検査） (文献 10 ; 自献例から提供)

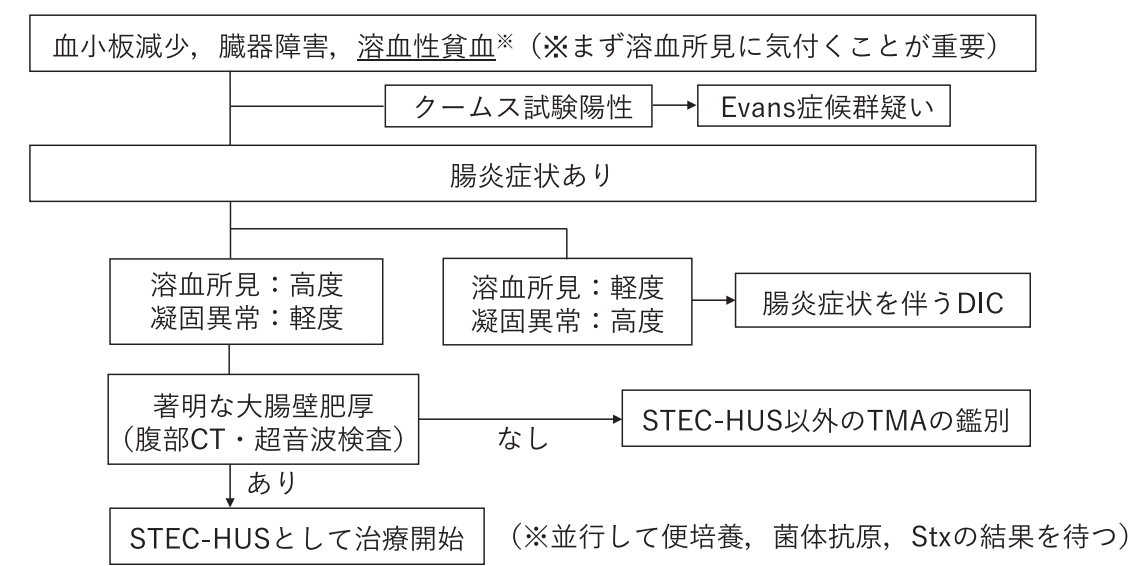

$\checkmark$ 上記の早期鑑別診断に従って治療開始（STEC-HUS: 支持療法, DIC: 抗菌薬など） 確定診断までは常に他のTMAやDICの可能性を考慮（図1の(1)〜5)を参照）

$\checkmark$ 並行してADAMTS13活性, STEC, 遺伝子検査, 原因疾患検査などの結果を待つ

図 4 STEC-HUS の腹部画像検査を用いた早期鑑別診断（図 1 の2の詳細） 〜腸炎症状を伴う DIC・TMA の早期鑑別診断〜

示す (図 4). 溶血所見 ( LDH, Hb, 破砕赤血球数, ハプトグロビンなど）が軽度で凝固異常（PT， FDP，D-dimer，ATなど）が高度であれば，腸炎症 状を伴う DIC として治療を開始する，次に，腸炎症 状を伴う他の TMA との鑑別として画像検查（腹部 $\mathrm{CT}$ 検查, 超音波検査) を行い, 著明な大腸壁肥厚を 認めればSTEC-HUS として治療を開始しつつ, 便培 養, 菌体抗原, Stxなどの結果を待つ。

\section{(3)二次性 TMA の早期鑑別診断}

〜特に二次性 TMA と DIC および aHUS の早期鑑別〜 二次性 TMA をきたす明らかな原因を認める場合
には診断は難しくなく, 原因となり得るものを知っ

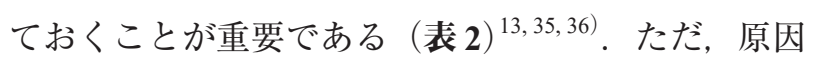
がすぐに確定できない場合や併存症がある例で, 特 にDIC および aHUS との鑑別に難啮することがある. 例えば，感染が疑われる症例では敗血症性 DIC との 鑑別が問題となる。また，妊娠を契機に aHUS を発 症することもあるので注意を要する.

二次性 TMA の早期診断について述べる. PLASMIC score や腸炎症状などから TTP および STEC-HUS を鑑別し, 原因疾患によって二次性 TMA と DIC を鑑別する. 二次性 TMA と DIC の原因がす ぐに確定し難い場合は, 溶血所見・凝固異常の程度 
表 2 二次性 TMA の原因

\begin{tabular}{|c|c|}
\hline $\begin{array}{l}\text { 自己免疫疾患 } \\
\text { (噖原病など) }\end{array}$ & $\begin{array}{l}\text { 全身性エリテマトーデス：㹂障害例で腎生検が鑑別に有用 } \\
\text { 強皮症：腎クリーゼ（悪性高血圧）もしくは強皮症による血管内皮障害 } \\
\text { 多発筋炎／皮膚筋炎, 抗リン脂質抗体症候群, 血管炎など }\end{array}$ \\
\hline 感染症 & $\begin{array}{l}\text { 細菌：肺炎球菌（直接クームス試験陽性），百日晐，溶連菌など } \\
\text { ウイルス：HIV，インフルエンザ, HCV, CMV, VZVなど }\end{array}$ \\
\hline 悪性腫瘍 & 消化器系癌, 乳癌, 前立腺癌, 肺癌など（進行固形癌が多い） \\
\hline 移植後 & $\begin{array}{l}\text { 造血幹細胞移植（同種移植で多い, カルシニューリン阻害薬の関与） } \\
\text { 臟器移植（腎, 肝, 心, 肺, 小腸など） }\end{array}$ \\
\hline 妊娠 & HELLP 症候群, 子㿍：妊娠契機の TTP およびaHUS との鑑別が必要 \\
\hline 薬剤 & $\begin{array}{l}\text { 抗悪性腫瘍薬：シスプラチン, チロシンキナーゼ阻害薬, VEGF 阻害薬, ゲムシタビン, マイトマイ } \\
\text { シン } \\
\text { 抗血小板薬：チクロビジン, クロピドグレル } \\
\text { 免疫抑制薬 : シクロスポリン, タクロリムス, シロリムス } \\
\text { その他 : バラシクロビル, キニーネ, 経口避妊薬, インターフェロンなど }\end{array}$ \\
\hline その他 & 悪性高血圧, コバラミン代謝異常症, 急性膵炎など \\
\hline
\end{tabular}

HIV: human immunodeficiency virus, HCV: hepatitis C virus, CMV: cytomegalovirus, VZV: varicella zoster virus, HELLP: hemolysis, elevated liver enzyme levels and a low platelet count syndrome, VEGF: vascular endothelial growth factor.

(文献 13，35，36より引用; 一部改変）

を指標に早期診断して治療を開始しつつ, 原因検査 (抗核抗体, ウイルス抗原・抗体, 血液培養, 画像検 査など）の結果を待つ. aHUS との早期鑑別が困難 な例もあり，その際には治療経過も含めて判断する 必要がある(後述).

\section{(4)aHUS の早期鑑別診断}

〜特に AHUS と DIC および二次性 TMA の早期鑑別〜 aHUS を疑った際には確定診断のために遺伝子検 査を行うが，その結果を待って治療開始するのは現 実的でなく, 臨床的に他の TMA および DICを除外 し, 臨床的 aHUS と診断して治療を開始する. aHUS を疑うにあたって，すぐに確認できるものとしては 補体関連異常の家族歴・既往歴および補体価（C3 低 下）が重要である。しかし，C3 低下例は約半数程度 であり，一方でC3 が正常でも aHUS を否定するこ とはできない，また，羊赤血球を用いた溶血試験も 有用であるが施行できる施設が限られる ${ }^{37)}$.

臨床的 aHUS の早期診断について述べる。 PLASMIC score や腸炎症状などから TTPおよび STEC-HUS を鑑別し, 原因の有無によって二次性
TMA およびDIC との鑑別をする．また， DIC との鑑 別においては, 溶血所見・凝固異常の程度も指標に する。 そして, 家族歴・既往歴および $\mathrm{C} 3$ 低下も参 考にし，他の TMA および DICが除外できた時点で 臨床的 aHUS として早期治療を開始する.

たた，補体関連異常の家族歴・既往歴が明らかな 場合には早期治療（エクリズマブ投与）をすぐに開 始できる症例もあるが, 実際には他の TMA および DIC を完全に除外するのがすぐには困難なことが多 い. 例えば，発症の初期に溶血所見がそしく敗血症 性 DIC として治療されるも, 後に溶血所見が顕在化 して aHUS と診断された症例もある ${ }^{38)}$. 二次性 TMA と診断された症例において, 遺伝子異常が報告され た例もある ${ }^{39)}$. また, aHUS を発症する遺伝子異常 がすべて解明されているわけではなく, 既知の遺伝 子異常がみつからなくとも aHUS を否定できない ${ }^{40)}$. 一方で, 補体関連の遺伝子異常を有していても aHUS を発症しないこともある ${ }^{41)}$.そのため, 実際には, DIC や二次性 TMA として治療を開始しつつ, 治療 反応性や経過も含めての判断を必要とすることが多 い.つまり, 治療経過が DIC や二次性 TMA に合致 
しない場合にこれらを臨床的に除外し, 臨床的 aHUS と診断する.

\section{おわりに}

TMA 領域は近年大幅に病態の解明が進み, 詳細に 分類・定義されるようになった。しかし， aHUS や 二次性 TMA などは未だ病態が不明な点も多く，ま た，確定診断に必要な検査について結果を得るのに 時間を要するものも多いため, 鑑別診断に難渋する 例がある。一方で, 病態の解明に伴って治療法も進 歩し, 早期治療介入により予後改善が得られるよう になってきている．その分，臨床医にとっては早期 診断の力量を問われると感じる.

今回, 血小板減少・臓器障害・貧血の診療におい て，よく遭遇する DIC と比較的稀な TMA の早期鑑 別を中心に，一刻も早く診断・治療を行いたいと思 う臨床医の視点を含めてまとめた。繰り返しになる が，血小板減少・臓器障害・溶血性貧血をみた際に まず重要な点は，「溶血性貧血」に気付くことであ る。そのためには，日常診療の中で $\mathrm{Hb}$ 低下と LDH 上昇のバランスなどを普段から意識することが重要 となる．溶血性貧血に気付くことが出来れば，TMA を鑑別に挙げることが可能となる。そして，血小板 減少・臓器障害・溶血性貧血の早期鑑別の要点を押 さえ可能性が高い疾患を選び出し，早期治療を開始 しつつ，確定診断が得られるまでは常に他の TMA やDICの可能性も念頭に置いて，治療経過の中で繰 り返し判断していく姿勢が大切である.

\section{著者全員の利益相反（COI）の開示：}

本論文発表内容に関連して開示すべき企業等との利 益相反なし

\section{文献}

1) 藤村吉博：特集：血栓性微小血管症（TMA）の最新の知 見. TMA-総論. 血栓止血誌 25: 675-681, 2014.

2) Gando S, Levi $\mathrm{M}$, Toh $\mathrm{CH}$ : Disseminated intravascular coagulation. Nat Rev Dis Primers 2: 16037, 2016.

3) Scully M, Cataland S, Coppo P, de la Rubia J, Friedman KD, Kremer Hovinga J, Lämmle B, Matsumoto M, Pavenski K, Sadler E, Sarode R, Wu H: International Working Group for Thrombotic Thrombocytopenic Purpura: Consensus on the standardization of terminology in thrombotic thrombo- cytopenic purpura and related thrombotic microangiopathies. J Thromb Haemost 15: 312-322, 2017.

4) 難治性疾患等政策研究事業「血液凝固異常症に関する調 査研究班」TTP グループ, 松本雅則, 藤村吉博, 和田英 夫, 小亀浩市, 宮川義隆, 上田恭典, 日笠聡, 森木隆典, 八木秀男, 宮田敏行, 村田満：血栓性血小板減少性紫斑 病 (TTP) 診療ガイドライン 2017. 臨血 58: 271-281, 2019.

5) Scully M, Hunt BJ, Benjamin S, Liesner R, Rose P, Peyvandi F, Cheung B, Machin SJ; British Committee for Standards in Haematology: Guidelines on the diagnosis and management of thrombotic thrombocytopenic purpura and other thrombotic microangiopathies. Br J Haematol 158: 323-335, 2012.

6) 五十嵐隆 : 溶血性尿毒症症候群の診断・治療ガイドライ ン作成班編：溶血性尿毒素症症候群の診断・治療ガイド ライン。東京, 東京医学社, 2014.

7) Ruggenenti P, Noris M, Remuzzi G: Thrombotic microangiopathy, hemolytic uremic syndrome, and thrombotic thrombocytopenic purpura. Kidney Int 60: 831-846, 2001.

8) Mayer CL, Leibowitz CS, Kurosawa S, Stearns-Kurosawa DJ: Shiga toxins and the pathophysiology of hemolytic uremic syndrome in humans and animals. Toxins (Basel) 4: 12611287, 2012.

9) Huang J, Motto DG, Bundle DR, Sadler JE: Shiga toxin B subunits induce VWF secretion by human endothelial cells and thrombotic microangiopathy in ADAMTS13-deficient mice. Blood 116: 3653-3659, 2010.

10) Yada $N$, Fujioka $M$, Bennett $C L$, Inoki $K$, Miki $T$, Watanabe A, Yoshida T, Hayakawa M, Matsumoto M, Fujimura Y: STEC: O111-HUS complicated by acute encephalopathy in a young girl was successfully treated with a set of hemodiafiltration, steroid pulse, and soluble thrombomodulin under plasma exchange. Clinical Case Reports 3: 208-212, 2015.

11) Takanashi J, Taneichi H, Misaki T, Yahata Y, Okumura A, Ishida Y, Miyawaki T, Okabe N, Sata T, Mizuguchi M: Clinical and radiologic features of encephalopathy during 2011 E. coli O111 outbreak in Japan. Neurology 82: 564-572, 2014.

12) Noris M, Remuzzi G: Atypical hemolytic - uremic syndrome. N Engl J Med 361: 1676-1687, 2009.

13) 香美祥二, 岡田浩一, 南学正臣, 要伸也, 丸山彰一, 安 田隆, 加藤秀樹, 吉田瑶子, 服部元史, 芦田明, 幡谷浩 史, 日高義彦, 澤井俊宏, 伊藤秀一, 藤丸季可, 藤村吉 博, 宮川義隆, 非典型溶血性尿毒症症候群診断基準改訂 委員会, 日本腎臓学会, 日本小児科学会, 日本血液学会, 日本血栓止血学会 : 非典型溶血性尿毒症症候群 (aHUS) 診療ガイド 2015. 日本腎臓学会誌 58: 62-75, 2016.

14) Cofiell R, Kukreja A, Bedard K, Yan Y, Mickle AP, Ogawa M, Bedrosian CL, Faas SJ: Eculizumab reduces complement activation, inflammation, endothelial damage, thrombosis, and renal injury markers in aHUS. Blood 125: 3253-3262, 2015.

15) Loirat C, Fakhouri F, Ariceta G, Besbas N, Bitzan M, Bjerre A, Coppo R, Emma F, Johnson S, Karpman D, Landau D, Langman CB, Lapeyraque AL, Licht C, Nester C, Pecoraro C, Riedl M, van de Kar NC, Van de Walle J, Vivarelli M, Frémeaux-Bacchi V; HUS International: An international consensus approach to the management of atypical hemolytic uremic syndrome in children. Pediatr Nephrol 31: 15-39, 2016.

16) Goodship TH, Cook HT, Fakhouri F, Fervenza FC, Frémeaux- 
Bacchi V, Kavanagh D, Nester CM, Noris M, Pickering MC, Rodríguez de Córdoba S, Roumenina LT, Sethi S, Smith RJ; Conference Participants: Atypical hemolytic uremic syndrome and C3 glomerulopathy: Conclusions from a "Kidney Disease: Improving Global Outcomes" (KDIGO) Controversies Conference. Kidney Int 91: 539-551, 2017.

17) Gando S, Saitoh D, Ogura H, Fujishima S, Mayumi T, Araki T, Ikeda H, Kotani J, Kushimoto S, Miki Y, Shiraishi S, Suzuki K, Suzuki Y, Takeyama N, Takuma K, Tsuruta R, Yamaguchi Y, Yamashita N, Aikawa N; Japanese Association for Acute Medicine Sepsis Registry Study Group: A multicenter, prospective validation study of the Japanese Association for Acute Medicine disseminated intravascular coagulation scoring system in patients with severe sepsis. Crit Care 17: R111, 2013.

18）朝倉英策, 高橋芳右, 内山俊正, 江口豊, 岡本好司, 川 杉和夫, 小林隆夫, 瀧正志, 辻仲利政, 松下正, 松野一 彦, 空岩清治, 矢冨裕, 和田英夫; 日本血栓止血学会 DIC 診断基準作成委員会 : 日本血栓止血学会 DIC 診断基 準 2017 年版. 血栓止血誌 28: 369-391, 2017.

19）丸山征郎, 坂田洋一, 和田英夫, 朝倉英策, 岡嶋研二, 丸藤哲, 射場敏明, 内場光浩, 内山俊正, 江口豊, 岡本 好司, 小倉真治, 川杉和夫, 久志本成樹, 小池薰, 古賀 震, 関義信, 空岩清治, 真弓俊彦 : 科学的根拠に基づい た感染症に伴うDIC 治療のエキスパートコンセンサス。 血栓止血誌 20: 77-113, 2009.

20) Asakura H: Classifying types of disseminated intravascular coagulation: Clinical and animal models. J Intensive Care 2: 20, 2014.

21) Rhodes A, Evans LE, Alhazzani W, Levy MM, Antonelli M, Ferrer R, Kumar A, Sevransky JE, Sprung CL, Nunnally ME, Rochwerg B, Rubenfeld GD, Angus DC, Annane D, Beale RJ, Bellinghan GJ, Bernard GR, Chiche JD, Coopersmith C, De Backer DP, French CJ, Fujishima S, Gerlach H, Hidalgo JL, Hollenberg SM, Jones AE, Karnad DR, Kleinpell RM, Koh Y, Lisboa TC, Machado FR, Marini JJ, Marshall JC, Mazuski JE, McIntyre LA, McLean AS, Mehta S, Moreno RP, Myburgh J, Navalesi P, Nishida O, Osborn TM, Perner A, Plunkett CM, Ranieri M, Schorr CA, Seckel MA, Seymour CW, Shieh L, Shukri KA, Simpson SQ, Singer M, Thompson BT, Townsend SR, Van der Poll T, Vincent JL, Wiersinga WJ, Zimmerman JL, Dellinger RP: Surviving Sepsis Campaign: International Guidelines for Management of Sepsis and Septic Shock: 2016. Intensive Care Med 43: 304-377, 2017.

22) Seymour CW, Gesten F, Prescott HC, Friedrich ME, Iwashyna TJ, Phillips GS, Lemeshow S, Osborn T, Terry KM, Levy MM: Time to Treatment and Mortality during Mandated Emergency Care for Sepsis. NEJM 376: 2235-2244, 2017.

23) Mesters RM, Mannucci PM, Coppola R, Keller T, Ostermann H, Kienast J: Factor VIIa and antithrombin III activity during severe sepsis and septic shock in neutropenic patients. Blood 88: 881-886, 1996.

24) Kienast J, Juers M, Wiedermann CJ, Hoffmann JN, Ostermann H, Strauss R, Keinecke HO, Warren BL, Opal SM; KyberSept investigators: Treatment effects of high-dose antithrombin without concomitant heparin in patients with severe sepsis with or without disseminated intravascular coagulation. J Thromb Haemost 4: 90-97, 2006.

25) Wiedermann CJ, Hoffmann JN, Juers M, Ostermann $H$,
Kienast J, Briegel J, Strauss R, Keinecke HO, Warren BL, Opal SM; KyberSept Investigators: High-dose antithrombin III in the treatment of severe sepsis in patients with a high risk of death: Efficacy and safety. Crit Care Med 34: 285-292, 2006.

26) Yada N, Nishio K, Seki T, Fukushima H, Urizono Y, Hata M, Okuchi K: Therapeutic effect of recombinant thrombomodulin on the hemostatic and inammatory response in patients with septic DIC. JAAM 22: 749-757, 2011.

27) Ito T, Thachil J, Asakura H, Levy JH, Iba T: Thrombomodulin in disseminated intravascular coagulation and other critical conditions - a multi-faceted anticoagulant protein with therapeutic potential. Crit Care 23: 280, 2019.

28）朝倉英策：血小板減少を伴う血栓疾患. DIC の診断. 血. 栓止血誌 30: 193-200, 2019.

29) Bendapudi PK, Hurwitz S, Fry A, Marques MB, Waldo SW, Li A, Sun L, Upadhyay V, Hamdan A, Brunner AM, Gansner JM, Viswanathan S, Kaufman RM, Uhl L, Stowell CP, Dzik WH, Makar RS: Derivation and external validation of the PLASMIC score for rapid assessment of adults with thrombotic microangiopathies: A cohort study. Lancet Haematol 4: e157-e164, 2017.

30) Li A, Khalighi PR, Wu Q, Garcia DA: External validation of the PLASMIC score: A clinical prediction tool for thrombotic thrombocytopenic purpura diagnosis and treatment. J Thromb Haemost 16: 164-169, 2018.

31) Sakai K, Wada H, Nakatsuka $Y$, Kubo M, Hayakawa M, Matsumoto M: Characteristics behaviors of coagulation and fibrinolysis markers in acquired thrombotic thrombocytopenic purpura. J Intensive Care Med (in press).

32) Takahashi H, Tatewaki W, Wada K, Niwano H, Shibata A: Fibrinolysis and fibrinogenolysis in disseminated intravascular coagulation. Thromb Haemost 63: 340-344, 1990.

33) Friedland JA, Herman TE, Siegel MJ: Escherichia coli O157: H7-associated hemolytic-uremic syndrome: Value of colonic color Doppler sonography. Pediatr Radiol 25: S65-S67, 1995.

34) 宮川義隆, 松本雅則, 南学正臣編 : 血栓性微小血管症 （TMA）診断・治療実践マニュアル．医薬ジャーナル社, 2016.

35) Matsuyama $T$, Kuwana $M$, Matsumoto $M$, Isonishi $A$, Inokuma S, Fujimura Y: Heterogeneous pathogenic processes of thrombotic microangiopathies in patients with connective tissue diseases. Thromb Haemost 102: 371-378, 2009.

36) Espinosa G, Bucciarelli S, Cervera R, Lozano M, Reverter JC, de la Red G, Gil V, Ingelmo M, Font J, Asherson RA: Thrombotic microangiopathic hemolytic anemia and antiphospholipid antibodies. Ann Rheum Dis 63: 730-736, 2004.

37) Yoshida $Y$, Miyata $T$, Matsumoto $M$, Shirotani-Ikejima $H$, Uchida Y, Ohyama Y, Kokubo T, Fujimura Y: A novel quantitative hemolytic assay coupled with restriction fragment length polymorphisms analysis enabled early diagnosis of atypical hemolytic uremic syndrome and identified unique predisposing mutations in Japan. PLoS One 10: e0124655, 2015.

38) Omura $T$, Watanabe E, Otsuka $Y$, Yoshida $Y$, Kato $H$, Nangaku M, Miyata T, Oda S: Complete remission of thrombotic microangiopathy after treatment with eculizumab in a patient with non-Shiga toxin-associated bacterial enteritis. Medicine 95: 27, 2016. 
39) Nester CM, Barbour T, de Cordoba SR, Dragon-Durey MA, Fremeaux-Bacchi V, Goodship TH, Kavanagh D, Noris M, Pickering M, Sanchez-Corral P, Skerka C, Zipfel P, Smith RJ: Atypical aHUS: State of the art. Mol Immunol 67: 31-42, 2015.

40) Noris M, Caprioli J, Bresin E, Mossali C, Pianetti G, Gamba S, Daina E, Fenili C, Castelletti F, Sorosina A, Piras R, Donadelli R, Maranta R, van der Meer I, Conway EM, Zipfel
PF, Goodship TH, Remuzzi G: Relative role of genetic complement abnormalities in sporadic and familial aHUS and their impact on clinical phenotype. Clin J Am Soc Nephrol 5: 1844-1859, 2010.

41) Thai HM: A Mechanistic Approach to the Diagnosis and Management of Atypical Hemolytic Uremic Syndrome. Transfus Med Rev 28: 187-197, 2014. 